\title{
Karakterisasi Morfologi Sifat Akustik dan Sifat Fisik Komposit Polypropylene Berpenguat Serat Dendrocalamus Asper untuk Otomotif
}

\author{
Angga Dea Saputra Hidayat , Moh. Farid dan Alvian Toto Wibisono, \\ Departemen Teknik Material, Fakultas Teknologi Industri, Institut Teknologi Sepuluh Nopember (ITS) \\ e-mail: mofaredo@gmail.com
}

\begin{abstract}
Abstrak-Kebisingan dapat mempengaruhi kenyamanan saat berkendara. Kebisingan yang disebabkan oleh lalu lintas memiliki tekanan bunyi 80-100 dB. Oleh karena itu pembuatan interior penumpang haruslah menggunakan material yang dapat mengabsorbsi suara. Sebelumnya sudah ada penelitian mengenai mengenai polypropylene berpenguat serat tandan kosong kelapa sawit dan diaplikasikan untuk interior mobil. Sehingga di penilitian ini menggunakan serat berpenguat bambu betung dengan permasalahan yang dikaji untuk mengetahui nilai koefisien absorpsi suara, sifat fisik, serta sifat mekanik. Komposisi fraksi berat serat yang digunakan adalah $10 \%, 15 \%$, 20\%. Tujuannya untuk mendapatkan nilai koefisien absorpsi suara terbaik. Dengan metode yang digunakan berdasarkan standartd ASTM E 1050 untuk pengujian absorbs suara. Komposit yang dibuat diharapkan mempunyai koefisien adsopsi suara yang bagus untuk diaplikasikan pada bagian interior kendaraan. Dari penelitian ini didapatkan kesimpulan, diantaranya nilai absorbsi suara yang terbaik diperoleh dari campuran $10 \%$ serat bambu betung dan $90 \%$ polypropylene dengan nilai $\alpha 0,5142$.
\end{abstract}

Kata Kunci-Sound Absorption Material, Interior, Serat Bambu Betung, Polypropylene,

\section{PENDAHULUAN}

$\mathrm{K}$ EBISINGAN yaitu bunyi yang tidak diinginkan dari usaha atau kegiatan dalam tingkat dan waktu tertentu yang dapat menimbulkan gangguan kesehatan manusia dan kenyamanan lingkungan (KepMenLH No.48 Tahun 1996)

saat ini di Indonesia telah banyak beredar mobil buatan negara maju yang dengan mudah didapatkan oleh masyarakat karena harga yang relatif terjangkau. Terlalu tingginya jumlah kendaraan akan menimbulkan permasalahan lingkungan. Namun di sisi lain, muncul kebutuhan untuk material baru dan inovatif yang mampu untuk memenuhi kebutuhan seperti efisien, ringan, dan tahan lama.

Material komposit merupakan area penelitian yang sangat luas dan telah menjadi solusi untuk banyak permasalahan. Beberapa teknologi sudah diterapkan penggunaan material komposit dari serat alam yang digunakan pada industri otomotif.

Pada penelitian ini, akan digunakan serat alam Dendrocalamus Asper atau jika pada bahasa Indonesia biasa kita sebut bambu betung. Dendrocalamus Asper memiliki karakteristik yang cukup baik. Tanaman ini biodegradable atau ramah lingkungan untuk diaplikasikan dalam material komposit. Selain itu kekuatan tanaman bambu juga cukup tinggi. Lalu kekuatan lentur dan impaknya juga tinggi untuk diaplikasikan dalam interior kendaraan. Sehingga serat dari Dendrocalamus Asper dapat dijadikan penguat (filler) pengganti kayu dalam proses pembuatan papan komposit plastik.

Dendrocalamus asper (Bambu Betung) ialah bambu yang amat kuat, dengan jarak ruas pendek, tetapi memiliki dinding yang tebal sehingga tidak begitu liat. Garis tengah bambu betung $80-130 \mathrm{~mm}$, panjang batang $10-20 \mathrm{~m}$. Bambu ini sering ditanam dan tumbuh pada daerah ketinggian 1900 mdpl. Di indonesia banyak sekali daerah yang menanam bambu betung seperti perkebunan bambu nusa verder yang ada di Sleman, D.I.Y. Jogjakarta, dan pada Desa Cengkrong, Kecamatan Pasrepan, Kabupaten Pasuruan. Untuk mendapatkan kualitas bambu yang maksimal, bambu betung dipanen pada umur 4 tahun.

Telah banyak penelitian mengenai pengaplikasian komposit dengan menggunakan serat alam sebagai material penyerap suara. Penelitian Farid dan Tri (2013) mengatakan bahwa komposit poliester berpenguat serat ramie pada frekuensi 1255 $\mathrm{Hz}$ memiliki nilai koefisien absorpsi suara $(\alpha)$ sebesar 0.835 [1]. Komposit polyester berpenguat bambu-rami dengan aspek rasio 90, nilai $\alpha$ serat rami mencapai 0.836 pada frekuensi 125 Hz. Serat bambu mencapai nilai a 0.972 pada frekuensi $1000 \mathrm{~Hz}$. Terdapat kenaikan secara signifikan nilai koefisien absorbsi suara pada frekuensi $125 \mathrm{~Hz}$ untuk material poliester berpenguat serat rami dan pada frekwensi menengah $1000 \mathrm{~Hz}$ untuk material poliester berpenguat serat bamboo [2].

\section{METODE PENELITIAN}

\section{A. Material}

Bahan yang digunakan dalam penelitian ini merupakan serat Dendrocalamus Asper berumur 4 tahun yang didapatkan dari desa Cengkrok, Kabupaten Pasuruan Provinsi Jawa Timur, Indonesia.

\section{B. Preparasi Spesimen}

Pengolahan serat Dendrocalamus Asper diawali dengan serat dibersihkan dari pengotor dengan menggunakan air bersih. Setelah bersih dan kering, serat Dendrocalamus Asper diperhalus dengan mesin pencacah organik. Serat yang sudah dicacah kemudian serat di-meshing untuk mendapatkan ukuran yang homogen pada rentang 280-900 mikron. Tahap terakhir yaitu menghilangkan kadar air serat dengan cara di- 
oven dengan temperatur $105^{\circ} \mathrm{C}$.

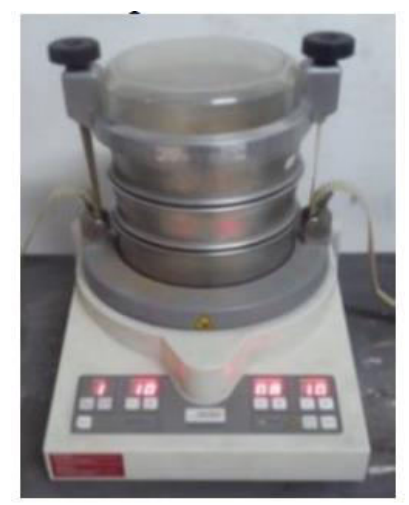

Gambar 1. Mesin sieving.

\section{Matriks Polypropylene}

Polypropylene merupakan salah satu jenis plastic yang paling ringan, dengan density sebesar 0,905 . Kristalinitas yang tinggi (Berada pada nilai diantara HDPE (High Density Polyethylene) dan LDPE (Low Density Polyethylene)) dari polypropylene menyebabkan sifatnya yang memiliki ketahanan tarik, kekakuan, dan kekerasan yang tinggi. Polypropylene memiliki rasio kekuatan tinggi berbanding berat yang sangat menguntungkan untuk diaplikasikan dalam berbagai hal. Produk jadi dari polypropylene biasanya memiliki permukaan yang mengkilat dan tidak mudah rusak. Titik luluh yang tinggi juga merupakan kelebihan dari polypropylene, termasuk ketahanan tarik pada temperatur tinggi [3].
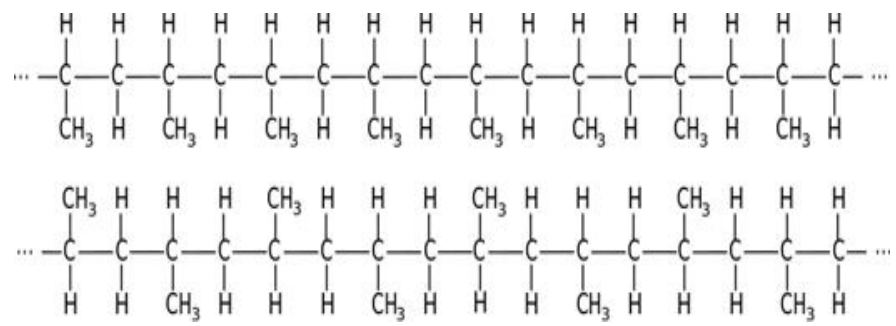

Gambar 2. Polypropylene (atas) Isotactic (bawah) Syndiotactic Fred W. Billmeyer, Jr, ( 1970).

Polypropylene memiliki sifat elektrik yang bagus, kelembaman kimia, serta ketahanan lembab seperti kebanyakan polymer hidrocarbon. Namun polypropylene kurang stabil jika dibandingkan dengan polyethilene ditinjau dari ketahanan panas, cahaya, dan gangguan oksidasi dan harus distabilkan dengan antioxidant dan penyerap cahaya ultraviolet untuk mendapat hasil yang bagus.

\section{Sifat Absorbsi Suara}

Ketika sumber bunyi bergetar, getaran yang terjadi pada setiap detik disebut frekuensi dan diukur dalam satuan Harzz $(\mathrm{Hz})$. Jumlah getaran yang terjadi setiap detik tersebut sangat tergantung pada jenis objek yang bergetar. Secara singkat, hal ini dapat diartikan sebagai bahan pembentuk objek tersebut. Oleh karena itu setiap benda akan memiliki frekuensi tersendiri yang berbeda dari benda lainnya. Dalam bahasa umum dapat diartikan bahwa benda memiliki kekhasan bunyi yang membedakannya dengan bunyi benda lain. Frekuensi terendah yang mampu didengar manusia berada pada $20 \mathrm{~Hz}$ sampai pada ambang batas atas $20.000 \mathrm{~Hz}$. Bunyi-bunyi yang muncul pada frekuensi di bawah $20 \mathrm{~Hz}$ disebut bunyi infrasonik, sedangkan yang rnuncul di atas $20.000 \mathrm{~Hz}$ disebut bunyi ultrasonik. Dalam rentang $20 \mathrm{~Hz}$ sampai $20.000 \mathrm{~Hz}$ tersebut, bunyi masih dibedakan lagi menjadi bunyi denga frekuensi rendah (dibawah $1000 \mathrm{~Hz}$ ), frekuensi sedang (1000$4000 \mathrm{~Hz}$ ) dan frekuensi tinggi (diatas $4000 \mathrm{~Hz}$ ). Frekuensi ini menyebabkan perbedaan tinggi rendahnya nada. Penelitian menunjukkan bahwa telinga anusia nyaman mendengarkan bunyi pada frekuensi rendah. Secara umum tingkat frekwensi yang dipakai dalam pengukuran akustiklingkungan adalah 125 . 250. 500. 1000. 2000 dan $4000 \mathrm{~Hz}$ atau 128. 256 .512. 1024. 2048. $2048 \mathrm{~Hz}$. Ketika suatu bunyi menumbuk pada suatu benda ataupun dinding, maka bunyi itu akan dipantulkan (reflected), diserap (absorb) dan diteruskan (transmitted) oleh benda tersebut Besarnya komposiis energi yang diserap atau dipantulkan akan menentukan sifat suatu material. Jika komposisi energi yang dipantulkan lebih besar, maka material tersebut bersifat sebagai pemantul (reflector). Jika energi yang diserap lebih besar, maka material tersebut bersifat penyerap. Standard yang digunakan untuk mengukur koefisien serap bahan adalah tabung impendasi dengan standarisasi menurut ASTM E-1050 [4]. Dimensi spesimennya berbentuk tabung dengan diameter $105 \mathrm{~mm}$ dan tinggi $10 \mathrm{~mm}$

Berikut ini adalah rangkaian impedansi untuk mengukur uji penyerapan suara.
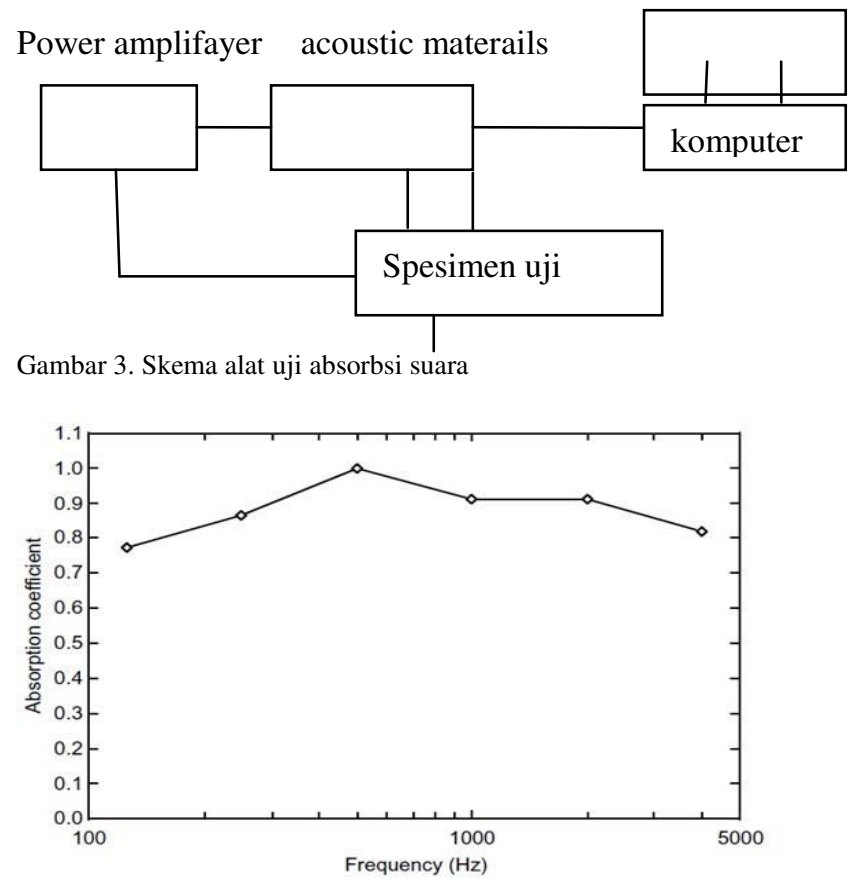

Gambar 4. Karakteristik Penyerapan Suara Helmholtz Absorber (Howard, 2009.

frekuensi kerja yang lebar (rendah, menengah, dan tinggi), maka harus digunakan gabungan ketiga bahan penyerap suara tersebut. Kombinasi antara proses gesekan dari komponen 
kecepatan gelombang suara dan resonansi dari komponen tekanan gelombang suara, akan membuat kinerja penyerapan energi suara oleh dinding atau partisi besar untuk seluruh daerah frekuensi. Material seperti ini disebut wideband absorber [5].

\section{E. Pengujian Scanning Electron Microscopy (SEM)}

Pengujian ini memiliki fungsi untuk mengetahui morfologi, ukuran partikel, pori serta bentuk partikel material. Standar yang digunakan adalah ASTM E2809 [6]. .Spesimen uji berbentuk balok kecil berukuran 10x10x3 mm ditunjukkan pada Gambar 4.

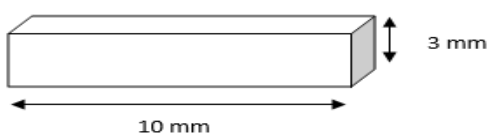

Gambar 5. Dimensi Spesimen SEM.

Prinsip kerja darii SEM adalah electron gun memproduksi electron beam, anoda menangkap electron beam untuk kemudian diarahkan ke sampel kemudian serangkaian lensa magnetik memfokuskan beam ini dan menembakkan ke sampel, scanner membaca struktur permukaan sampel selanjutnya menangkap sinyal dari secondary dan back scattered electron untuk dikirim ke sistem kontrol sehingga dapat dilihat gambarnya pada monitor seperti gambar dibawah berikut:

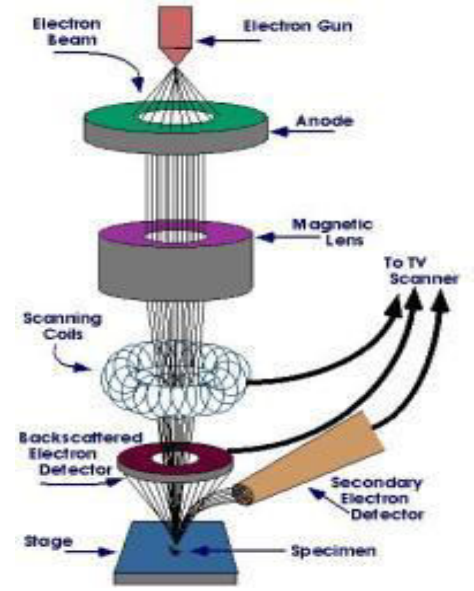

Gambar 6. Prinsip kerja SEM (W. Zho SEM 2007).

\section{F. Pengujian Flexural}

Kekuatan lentur digunakan untuk menunjukkan kekakuan dari suatu material ketika dibengkokkan. Pengujian kelenturan dilakukan dengan metode three point bend, dimana spesimen diletakan pada kedua tumpuan dan dilakukan pembebanan ditengah specimen Mesin yang digunakan adalah mesin uji bending milik Unair Surabaya. Prosedur pengujian menurut standar ASTM D790. Dimensi spesimen yang diuji sesuai standart tersebut ialah sebesar $128 \times 25 \times 4 \mathrm{~mm}$. [7].

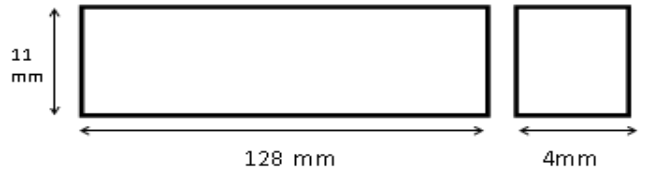

Gambar 7. Dimensi Spesimen Uji Flexural.

Kekuatan lentur suatu material dapat dihitung dengan persamaan berikut:

$$
\sigma_{\mathrm{f}}=\frac{3 \mathrm{P}}{2 \mathrm{~d}^{2}}
$$

Keterangan :

$\sigma_{\mathrm{f}}=$ Kekuatan Lentur $\left(\mathrm{Kg} / \mathrm{cm}^{2}\right)$

$\mathrm{L}=$ Support $\operatorname{span}(\mathrm{cm})$

$\mathrm{P}=$ Beban patah $(\mathrm{Kg})$

$\mathrm{b}=$ lebar spesimen $(\mathrm{cm})$

$\mathrm{d}=$ tebal spesimen $(\mathrm{cm})$

\section{HASIL DAN PEMBAHASAN}

\section{A. Hasil Pengujian Absorbsi Suara}

Pengujian Serat Dendrocalamus Asper memiliki Semakin besar nilai $\alpha$ maka semakin baik digunakan sebagai peredam suara.

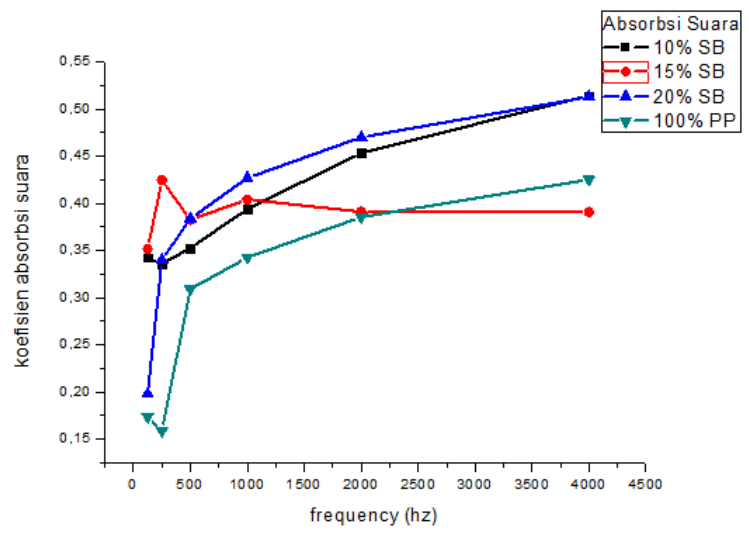

Gambar 8. Grafik Nilai Koefisien Absorbsi Suara polypropylene Murni dan komposit serat $10 \%, 15 \%, 20 \%$.

Semakin besar nilai $\alpha$ maka semakin baik digunakan sebagai peredam suara. Nilai $\alpha$ memiliki range 0 sampai 1 dapat dilihat pada tabel dibawah berikut pada $4000 \mathrm{~Hz}$ di komposisi seratmemiliki daya serap yang sangat bagus

Dari gambar grafik di atas menunjukkan hasil absorbsi suara memiliki Hasil pada spesimen komposit (10\%B-90\%PP) terlihat bahwa spesimen dengan komposisi ini mempunyai kemampuan penyerapan suara yang baik pula. Pada frekuensi rendah nilai $\alpha$ (koefisien absorbsi)nya sebesar 0,3426 pada frekuensi $125 \mathrm{~Hz}$, pada frekuensi 250 sampai $1000 \mathrm{~Hz}$ nilai $\alpha$ naik secara konstan hingga 0,3940 sehingga pada frekuensi $2000 \mathrm{~Hz}$ mengalami kenaikan penyerapan suara yang sangat baik di dapat nilai $\alpha 0,4533$. Sehingga kemampuan penyerapan suara yang tertinggi pada frekuensi $4000 \mathrm{~Hz}$ dengan nilai $\alpha$ tertinggi 0,5142

Dari pengujian absorbsi suara tersebut bertambah nilai $\alpha$ akan memiliki nilai yang bagus pula, di spesimen $10 \%$ serat ini 
memiiki nilai $\alpha$ pada frekuensi $4000 \mathrm{~Hz}$ dibandingkan dengan spesimen lainnya dikarenakan spesimen ini memiliki rongga yang mungkin terisi udara dimungkinkan porositas komposit relatif besar, sehingga mempunyaai koefisien absorb yang lebih tinngi pada frekuensi standart maupun tinggi.

\section{B. Hasil Pengujian Scanning Electron Microscopy (SEM)}

Pengujian Scanning Electron Microscopy (SEM) bertujuan untuk mengetahui dan menganalisa morfologi dari Serat Dendrocalamus Asper. Pada pengujian SEM ini Serat Dendrocalamus Asper dilapisi dengan coating AuPd. Setelah itu spesimen di masukkan ke dalam alat uji SEM dan diambil data gambar.

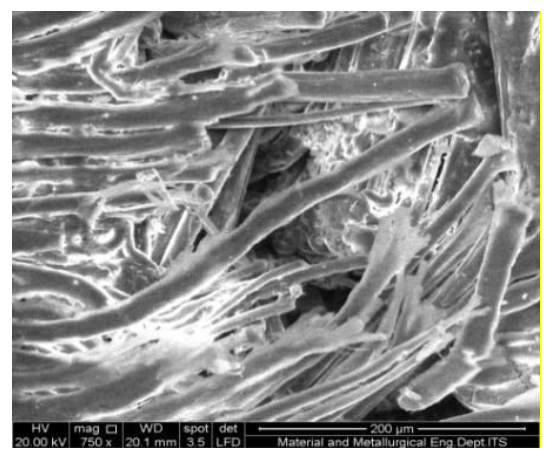

Gambar 9. Hasil Uji SEM Serat Dendrocalamus Asper Perbesaran 200x Dan 700x.

Gambar 9 menunjukkan Serat Dendrocalamus Asper tanpa perlakuan alkali (belum dikenai perlakuan kimia) dengan perbesaran 1000x, menunjukkan serat yang masih kasar dengan ukuran diameter sekitar $200 \mu \mathrm{m}$ serta masih mengalami penggumpalan. Morfologi yang kasar ini disebabkan oleh kandungan lapisan lilin, substansi lemak, dan pengotor [8]. Nilai absorbsi suara material komposit ini, jumlah morfologi yang banyak tersebut meningkatkan kemampuan absorbsi material komposit dengan PP 90\% dan serat 10\% ini.hasil SEM menunjukan serat tidak seoenuhnya terisi polimer polypropylene dan terlihat adanya rongga-rongga yang mungkin terisi udara dimungkinkan porositas komposit relatif besar, sehingga mempunyaai koefisien absorb yang lebih tinngi pada frekuensi standart maupun tinggi.

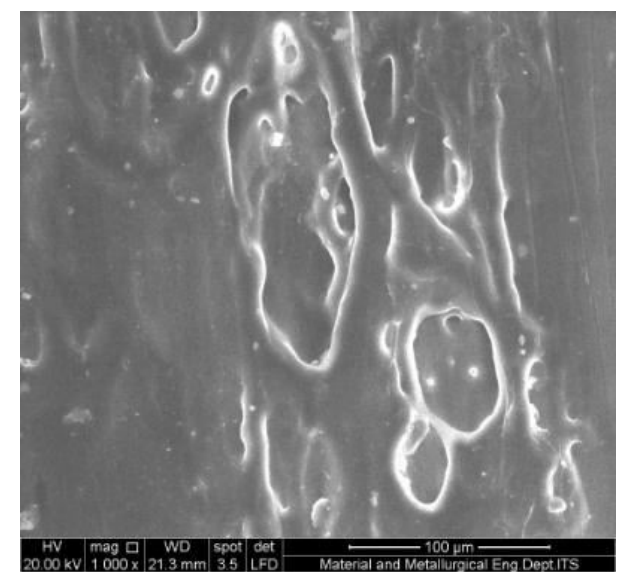

Gambar 10. Hasil SEM Dengan Polypropylene 100\% Perbesaran 1000x.
Hasil sem dari material komposit pure polypropylene memiliki matriks polypropylene terlihat rapat dan solid. Berdasarkan penilitian absprbsi suara yang dihasilkan.

Dari penghamburan energi akustik menjadi energi panas. Selain itu osilaasi ini juga menyebabkan gesekan sehingga timbul panas sehingga energi suara berubah menjadi energi panas. Selain itu osilasi ini juga menyebabkan berubahnya arah dari gelombang suara tersebut dan mengeluarkan nya ke sehgala arah sehingga gelombang suara kehilangan momentum untuk memantul ke arah datangnya [9].

\section{Hasil pengujian flexural}

Dari tabel dibawah ini masing2 material mempunyai kekuatan lentur yang sangat berbeda di karenakan tergantung fraksi material tersebut.

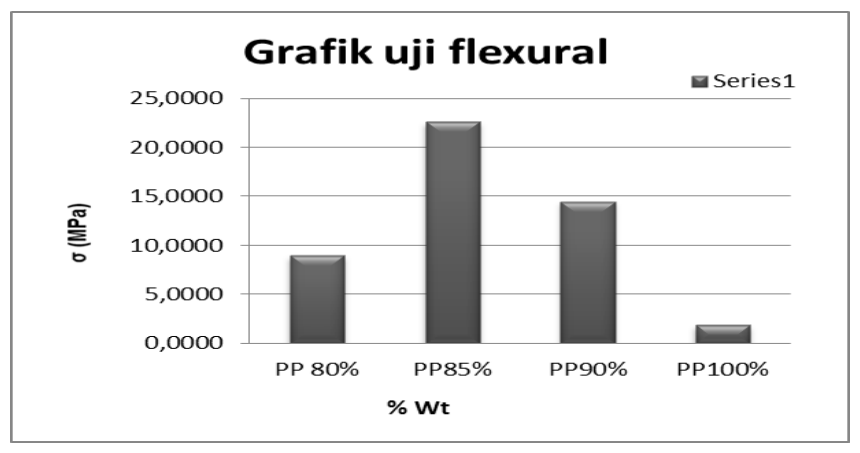

Gambar 11. Hasil Grafik Pengujian Flexural

Dari gambar 8 diatas dapat diketahui bahwa pada komposit specimen $85 \% \mathrm{PP}$ (polypropylene)mempunyai nilai kekuatan lentur tertinggi sebesar 22,62 Mpa. Pada spesimen komposit 90\% polypropylene kekuatan lentur sebesar 14,47 Mpa. Sedangkan pada spesimen komposit $100 \%$ polypropylene mempunyai nilai kekuatan lentur yang paling rendah yaitu sebesar 1,87 Mpa. Pada spesimen 80\% polypropylene memiliki kekuatan lentur sebesar 8,96 Mpa Berdasarkan hasil pengujian, nilai kekuatan lentur terendah ada pada spesimen komposit $80 \%$ polypropylene sebesar $1,87 \mathrm{Mpa}$

Dari hasil pengujian lentur didapatkan hasil bahwa 85\% PP mempunyai nilai kelenturan yang sangat tinggi. Hal ini dikarenakan waktu pencampuran antara serat dengan matriks merata sehingga bisa dikatakan homogen.

\section{KESIMPULAN}

Berdasarkan hasil dari penelitian dan pembahasan maka dapat disimpulkan:

1. Nilai koefisien absorbsi suara komposit Polypropylene berpenguat serat Dendrocalamus Asper. yang terbaik pada material 10\% serat dengan 90\% Polypropylene didapatkan hasil tertinggi pada frekuensi $4000 \mathrm{~Hz}$ dengan nilai $\alpha$ tertinggi 0,5142 .

2. Berdasarkan dari hasil Scanning Electron Microscopy (SEM) dapat diketahui $10 \%$ serat Dendrocalamus Asper -90\%Polypropylene memiliki struktur dengan pori yang paling bagus di bandingkan dengan spesimen lainnya 
yang menjelaskan penyebab nilai $\alpha$ terbesar terdapat pada spesimen ini pada serat Dendrocalamus Asper

3. Nilai kekuatan lentur komposit Polypropylene berpenguat serat serat Dendrocalamus Asper mangalami kenaikan seiring penambahan fraksi massa seratnya, akan tetapi pada $10 \%$ serat kekuatan lentur menurun karena poros yang ada pada komposit semakin besar. Nilai kekuatan lentur komposit polypropylene berpenguat serat Dendrocalamus Asper terbesar didapatkan pada fraksi massa $15 \%$ serat, dengan nilai flexural strength sebesar 22,6276 Mpa

\section{UCAPAN TERIMA KASIH}

Penulis mengucapkan terimakasih kepada program Penelitian Unggulan Perguruan Tinggi, Kemenristekdikti tahun 2017 yang telah mendukung pendanaan dalam penelitian ini.

\section{DAFTAR PUSTAKA}

M. Farid and T. Heryanto, "Correlation of Normal Incidence Sound Absorption Coefficient (NAC) and Random incidence Sound
Absorption Coeffiecient (RAC) of Polyester/Ramie Fibre Composite Materials," Adv. Mater. Res., vol. 789, pp. 269-273, 2013.

[2] M. Farid, H. Ardhyananta, V. M. Pratiwi, and S. P. Wulandari, "Correlation between Frequency and Sound Absorption Coefficient of Polymer Reinforced Natural Fibre," Adv. Mater. Res., vol. 1112, pp. 329-332, 2015.

[3] W. Fred and J. Billmeyer, "Effect of maleic anhydride -gpolypropylene," 1970.

[4] ASTM-E1050-98, "Standard test method for impedance and absorbtion of acoustical material using a tube, two microphones, and digital frequency analysis system."

[5] Howard, M. David, Angus, and A. Jamie, Acoustics and Pshycoacoustic. Burlington: Focal Press, 2009.

[6] L. Wrench, "FEI Compact Inspect ${ }^{\mathrm{TM}}$," 2017. .

[7] ASTM D790, "Standard test methods for flexural properties of unreinforced and reinforced plastics and electrical insulating materials," Am. Soc. Test. Mater., vol. 8, no. 1.

[8] J. Rout, M. Misra, S. S. Tripathy, S. K. Nayak, and A.K. Mohanty, "The Influence of Fibre Treatment on The Performance of CoirPolyester Composites," Compos. Sci. Technol., vol. 61, pp. 13031310, 2001.

[9] W. Zhou, R. Apkarian, Z. L. Wang, and D. Joy, Fundamentals of Scanning Electron Microscopy (SEM), Scanning Microscopy for Nanotechnology. 2007. 